\title{
Short-term anti-vascular endothelial growth factor treatment elicits vasculogenic mimicry formation of tumors to accelerate metastasis
}

\author{
Yuan $\mathrm{Xu}^{1 \dagger}$, Qin $\mathrm{Li}^{1 \dagger}$, Xiao-Yu Li ${ }^{2}$ Qiu-Ya Yang ${ }^{1}$, Wei-Wei Xu² and Gao-Lin Liü ${ }^{1 *}$
}

\begin{abstract}
Background: Antiangiogenic therapy is one of the most significant advances in anticancer treatment. The benefits of antiangiogenic therapies of late-stage cancers have been investigated but are still too limited.

Methods: We used an ovarian cancer model to test the effect of short-term bevacizumab treatment on metastasis as measured by bioluminescence. Western blotting and CD34-PAS dual staining were performed to assess hypoxiainducible transcription factor- $1 \alpha$ (HIF-1 $\alpha$ ) expression and vasculogenic mimicry(VM) formation. Cell viability was examined by a CCK8 assay.
\end{abstract}

Results: Bevacizumab demonstrated antitumor effects in models of ovarian cancer, but also accelerated metastasis together, with marked hypoxia and VM formation in mice receiving short-term therapy. Bevacizumab treatment did not affect SKOVZ cell viability and the amount of VM in three-dimensional culture.

Conclusion: These results suggest that antiangiogenic therapy may potentially influence the progression of metastatic disease, which has been linked to the hypoxic response and VM formation.

Keywords: Antiangiogenic therapies, Metastasis, Hypoxia, Vasculogenic mimicry

\section{Background}

Tumors can grow to a maximum diameter of between 1 and $2 \mathrm{~mm}$ before their metabolic demands are restricted due to the diffusion limit of oxygen and lack of essential nutrients. To exceed this size or spread to other organs, tumors require an independent blood supply. In the 1970 s, Folkman et al was the first to propose the concept of antiangiogenesis as a therapeutic approach to treat solid tumors [1]. Targeting the blood supply by inhibiting the formation of blood vessel will lead to tumor growth arrest. Numerous angiogenesis inhibitors have been therapeutically used in both preclinical and clinical settings [2]. Vascular endothelial growth factor (VEGF) receptor tyrosine kinase inhibitors and a VEGFneutralizing antibody have been clinically validated to target VEGF or its receptors as an anticancer treatment.

\footnotetext{
* Correspondence: gaolinliu@yahoo.com.cn

† Contributed equally

'Department of Pharmacy, Shanghai First People's Hospital, School of medicine, Shanghai Jiao Tong University, No.100 Haining Road, Shanghai, 200080, China

Full list of author information is available at the end of the article
}

However, a number of limitations are observed in current antiangiogenic therapies. Many clinical benefits are short-lived, and enduring clinical responses are rare. While numerous trials have shown an increase in survival after patients are treated with antiangiogenic therapy, the increase for many was only a matter of months [3]. Moreover, single-agent use of antiangiogenesis appears to be insufficient to improve patient survival [4]. While any improvement in overall survival for patients should be regarded as advancement, it is importart to understand why such clinical improvements are sometimes transitory so that new therapies result in more enduring benefits.

One explanation for these limitations is a potential link between antiangiogenic therapy and increased metastasis [5]. In RIP-Tag2 mice treated with the VEGF receptor 2-inhibitor DC101, although tumors were smaller, they showed significantly more invasive and malignant phenotypes, with most showing wide fronts of invasion into urrounding acinar tissues [6]. Rodents treated with an anti-VEGF antibody showing a striking 
increase in the number and total area of small satellite tumors compared with those that had not received antiangiogenic therapy, and tumor cells often had migrated over long distances $[7,8]$. Together, these results suggest that antiangiogenic therapy may influence the progression of metastatic disease. To understand the reasons for these observations and to enable enduring benefits of antiangiogenic therapies, we examined the effect of a VEGF-neutralizing antibody on metastasis in mice after short-term administration. Furthermore, the hypoxic response and vasculogenic mimicry (VM) formation were assessed in this study.

\section{Materials}

\section{Antibodies}

For western blotting and histopathological analyses, a mouse anti-HIF- $1 \alpha$ monoclonal antibody was purchased from Novus Biologicals (Littleton, CO, USA), CD34 monoclonal antibody from Abgent (San Diego, CA, USA).

\section{Cell lines}

The human ovarian cancer cell line SKOV3 was purchased from the ATCC and transfected with a luciferase-expressing lentivirus containing an independent open-reading frame of GFP. After 72 hours, cells were examined by fluorescence microscopy to confirm infection. Luciferase expression was determined using luciferin and an in vivo imaging system (Xenogen). Cells were maintained in RPMI-1640 medium supplemented with $10 \%$ heatinactivated fetal bovine serum (Gibco Invitrogen Corp), and incubated at $37^{\circ} \mathrm{C}$ in a humidified atmosphere containing $5 \% \mathrm{CO}_{2}$.

\section{Three-dimensional(3D) cultures}

Matrigel (BD Biosciences) was placed dropwise onto glass coverslips in 12-well culture plates and allowed to polymerize for $30 \mathrm{~min}$ at $37^{\circ} \mathrm{C}$. SKOV3 cells were then seeded onto the 3D matrix in complete medium.

\section{Animal models}

SKOV3 ${ }^{\mathrm{LUC}+}$ cells $\left(1.2 \times 10^{6}\right.$ cells $)$ were directly injected into the tail vein of 6-8-week-old female nude mice. Forty mice were assigned into four groups(A, B, C and D). Group A was treated with phosphate-buffered saline (PBS) bi-weekly for 3 weeks. Group B was treated with $40 \mathrm{mg} / \mathrm{kg}$ bevacizumab bi-weekly for 3 weeks. Group C was treated with $3 \mathrm{mg} / \mathrm{kg}$ cisplatin weekly for 3 weeks. Group D was treated with both bevacizumab bi-weekly and cisplatin weekly for 3 weeks. Bevacizumab and cisplatin were administered intraperitoneally. Body weight was measured and recorded weekly. Metastatic disease progression in $\mathrm{SKOV} 3^{\mathrm{LUC}+}$ tumor-bearing mice was monitored. Before mice were anesthetized with Forane, an aqueous solution of luciferin $(150 \mathrm{mg} / \mathrm{kg})$ was intraperitoneally injected at $10 \mathrm{~min}$ prior to imaging. Mice were placed into the light-tight chamber of a CCD camera system (Xenogen), and photons emitted from luciferase-expressing cells within mice were quantified for 1 min, using the software program living. Four weeks after initial treatment, all mice were sacrificed to assess the effects of drug treatments. All procedures involving mice complied with the Guide for the Care and Use of Laboratory Animals (National Institutes of Health).

\section{Western blotting}

The tissues were homogenized in $0.5 \mathrm{ml}$ Hepes $(50 \mathrm{mM}$, $\mathrm{pH}$ 7.5) containing $100 \mathrm{mM} \mathrm{NaCl}, 1 \mathrm{mM} \mathrm{CaCl}_{2}, 1 \mathrm{mM}$ dithiothreitol, $1 \%$ ethylene glycol-bis(aminoethyl ether)tetraacetic acid $1 \%$ Triton X-100 and proteinase inhibitors. Protein extracts were kept in ice for $30 \mathrm{~min}$ and then centrifuged at $14,000 \mathrm{~g}$ at $4^{\circ} \mathrm{C}$ for $30 \mathrm{~min}$. Protein concentrations were determined using a bicinchoninic acid protein assay reagent kit. Protein samples $(20 \mathrm{mg})$ were mixed with equal volumes of loading buffer $(20 \%$ glycerol, $4 \%$ sodium dodecyl sulfate, and $100 \mathrm{mM}$ Tris$\mathrm{HCl}, \mathrm{pH}$ 6.8) and then boiled for $5 \mathrm{~min}$ in the presence of $\beta$-mercaptoethanol. Proteins were separated in $8 \%$ sodium dodecyl sulfate-polyacrylamide gels at $100 \mathrm{~V}$ for $2 \mathrm{~h}$ and then electrotransferred to nitrocellulose membranes at $270 \mathrm{~mA}$ for $2 \mathrm{~h}$. Membranes were blocked with $5 \%$ non-fat dry milk in PBS with $0.1 \%$ Tween 20 for $1 \mathrm{~h}$ at room temperature. Then, membranes were incubated with anti- HIF- $1 \alpha(1: 500)$ overnight at $4{ }^{\circ} \mathrm{C}$ and finally with a horseradish peroxidase-conjugated anti-mouse IgG for $1 \mathrm{~h}$ at room temperature after washing with TBS containing $0.1 \%$ Tween 20 . Proteins were visualized by enhanced chemiluminescence reagents after washing. Protein expression was semi-quantified using an image analysis system.

\section{CD34-PAS dual staining}

Four micrometer paraffin sections were routinely deparaffinized and dehydrated. First, CD34 immunohistochemical staining was applied to the sections. Endogenous peroxidase activity was blocked with $3 \%$ hydrogen peroxide in $50 \%$ methanol for $10 \mathrm{~min}$ at room temperature. Sections were rehydrated and washed with PBS and then pretreated with citrate buffer (0.01 M citric acid, $\mathrm{pH}$ 6.0) for $20 \mathrm{~min}$ at $100^{\circ} \mathrm{C}$ in a microwave oven. Non-specific binding sites were blocked with $2 \%$ normal goat serum in PBS for 20 min at $37^{\circ} \mathrm{C}$. Sections were then incubated overnight at $4^{\circ}$ $\mathrm{C}$ with anti-CD34 at a 1:200 dilution. Then, sections were rinsed with PBS and incubated with biotinylated goat antimouse IgG for $20 \mathrm{~min}$ at $37^{\circ} \mathrm{C}$, followed by incubation with 3,3'-diaminobenzidine(DAB) chromogen for $10 \mathrm{~min}$ at room temperature. Sections were then rinsed with water for $1 \mathrm{~min}$ to stop the DAB-staining reaction. 
Formalin and melanin granules were then removed using the methods mentioned above. Finally, sections were treated with $0.5 \%$ periodic acid solution for $10 \mathrm{~min}$ and rinsed with distilled water for 2-3 min. In a dark chamber, sections were treated with Schiff solution for 15-30 min. After rinsing with distilled water, sections were counterstained with hematoxylin [9].

\section{Cell counting kit 8 (CCK8) assay}

Cell viability was measured by conversion of Dojindo's highly water-soluble tetrazolium salt WST-8 to a yellowcolored watersoluble formazan (CCK8 assay). The amount of formazan dye generated by the activity of mitochondrial dehydrogenases in cells is directly proportional to the number of living cells. CCK8 is more sensitive than the 3(4,5-dimethylthiazol-2-yl)-2, 5-diphenyltetrazolium bromide assay [10]. SKOV3 cells were trypsinized and seeded at $5 \times 10^{3}$ cells/well in 96 well plates in 3D cultures. After $24 \mathrm{~h}$, various concentrations of bevacizumab were added, followed by incubation for another $48 \mathrm{~h}$. Then, $10 \mu \mathrm{L}$ CCK8 (Sigma, USA) solution in PBS was added to each well. Plates were incubated for an additional $2 \mathrm{~h}$. The optical density of each well was measured using a microculture plate reader at a $490 \mathrm{~nm}$ wavelength.

\section{Statistical analysis}

All results were evaluated using the SPSS 13.0 statistical software package. Data were analyzed using one-way ANOVA. Results were expressed as the mean \pm standard deviation, and $\mathrm{P}<0.05$ was considered statistically significant.

\section{Results}

Increased metastasis after short-term treatment with the angiogenesis Inhibitor bevacizumab

In our study, a model of metastasis was used to test the effect of short-term bevacizumab treatment. SKOV3 ${ }^{\mathrm{LUC}+}$ cells expressing luciferase were directly injected into the tail vein of female nude mice and then received bevacizumab and/or cisplatin treatment for 3 weeks. Forty mice were equally divided into four groups at random (PBS, bevacizumab, cisplatin and bevacizumab + cisplatin groups). Tumor growth and metastasis were monitored by bioluminescence at 1 and 4 weeks after treatment. Mean photon counts of each group were quantified, and the ratio of metastasis was measured. The pulmonary metastasis rate was $100 \%$. Tumor growth delay was observed at 1 week after bevacizumab and/or cisplatin treatments, without extrapulmonary metastasis. Short-term bevacizumab treatment resulted in accelerated extrapulmonary metastasis at 4 weeks after treatment. Extrapulmonary metastases were found in livers and legs. Cisplatin and bevacizumab + cisplatin treatment inhibited tumor growth, compared with that of PBS treatment.. While no significant difference in tumor growth was observed between bevacizumab and control groups (Figure 1).

\section{Hypoxia is implicated in the adaptive response}

To gain an insight into possible molecular mechanisms of the increased metastasis, we determined whether hypoxia development was concomitant with metastasis. Mice were assigned into four groups (PBS, bevacizumab, cisplatin and bevacizumab + cisplatin) and received bevacizumab and/or cisplatin treatments for 3 weeks. Four weeks after initial treatment, five mice from each group were sacrificed for examination. Expression of HIF-1 $\alpha$ in pulmonary tumor nodules was analyzed by western blotting. In PBS and cisplatin groups, most tumors showed little hypoxia. In contrast, mice that received bevacizumab and bevacizumab + cisplatin therapy showed a markedly increased level of HIF- $1 \alpha$ expression (Figure 2). Differences in HIF-1 $\alpha$ protein levels in each group were considered statistically significant.

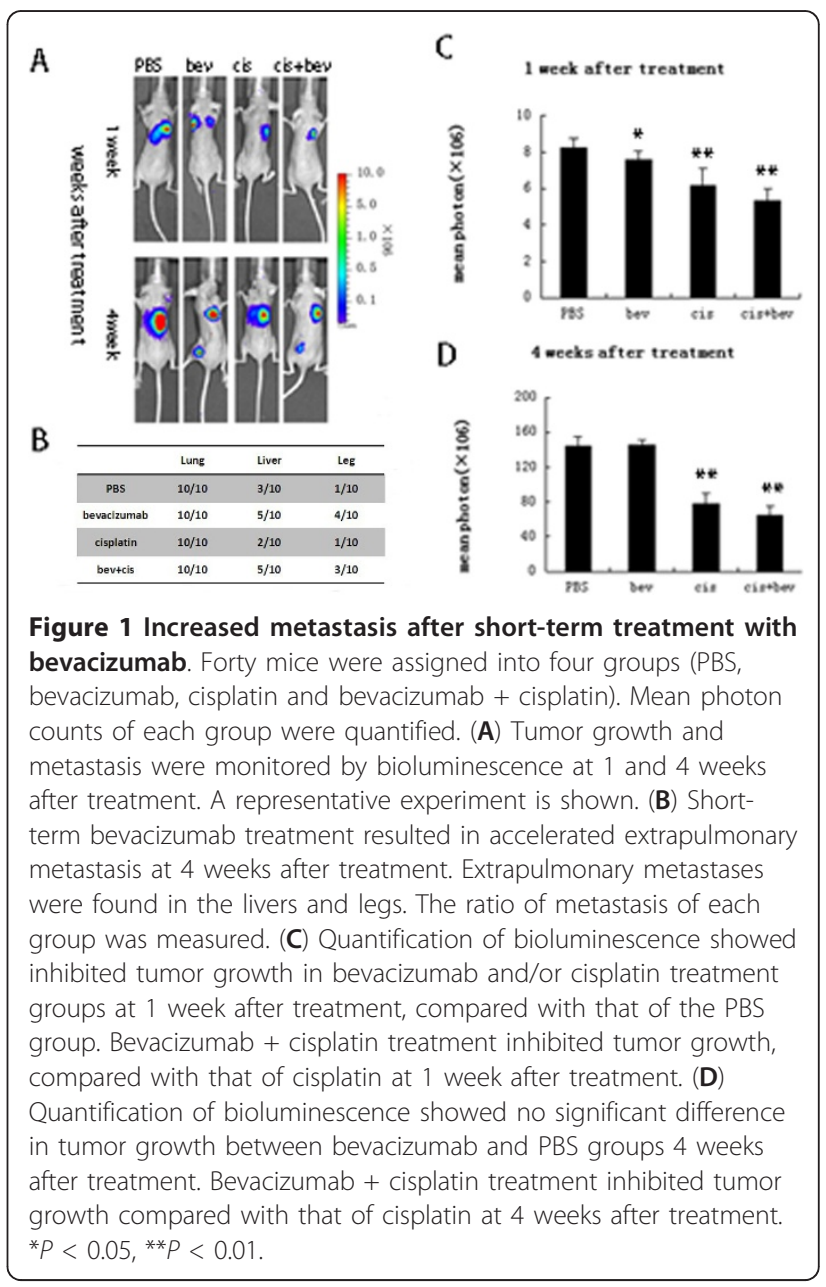




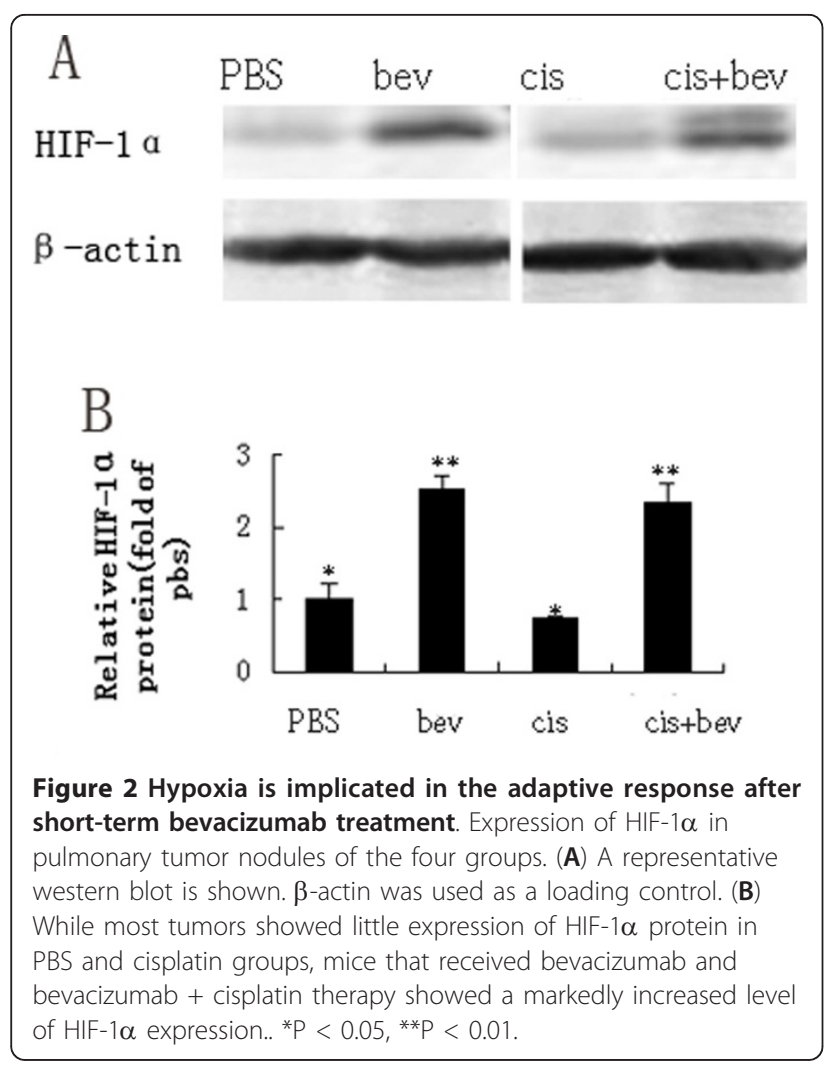

\section{Anti-VEGF treatment also induces increased VM}

The definition of VM is that tumor cells mimic endothelial cells and form vasculogenic networks. CD34-PAS double staining was used to distinguish VM and endothelial-dependent vessels. CD34 is a marker of endothelial cells, and the basement membrane is positive for PAS. Therefore, we counted PAS-positive and CD34-negative vessels for indicate. Mice were assigned into four groups (PBS, bevacizumab, cisplatin and bevacizumab + cisplatin) that received bevacizumab and/or cisplatin treatments for 3 weeks. Four weeks after initial treatment, five mice from each group were sacrificed for examination. Tumors in the bevacizumab group formed more VM channels than those of PBS and cisplatin, and bevacizumab + cisplatin groups (Figure 3 ).

\section{In vitro experiment demonstrating the effect of} bevacizumab on VM

SKOV3 cells were cultured in 3D culture, which formed VM channels. Then, we compared the cell viability and the ability to form VM in 3D culture after treatment with bevacizumab $(0,1,10,100$ and $1000 \mu \mathrm{g} / \mathrm{ml})$ for up to $48 \mathrm{~h}$. Cell viability was examined by a CCK 8 assay. Bevacizumab treatment did not affect SKOV3 cell viability and the number of tubules (Figures 4 and 5).
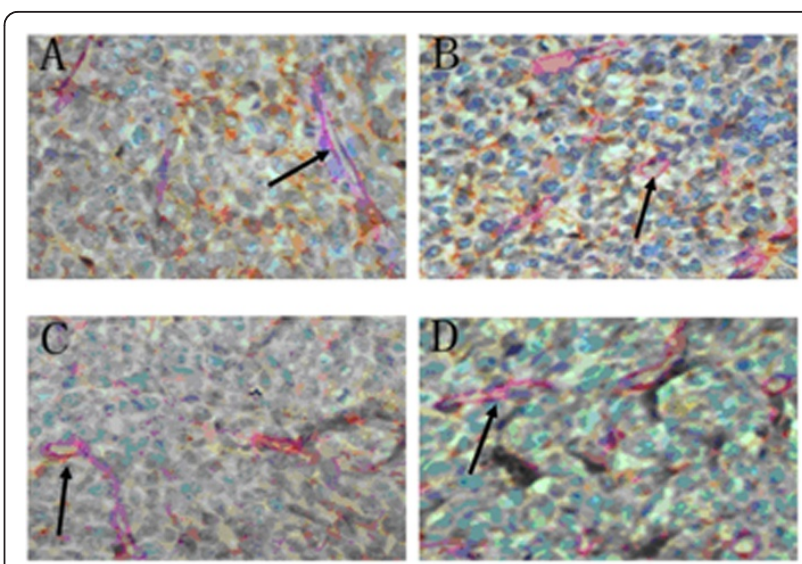

$\mathrm{E}$

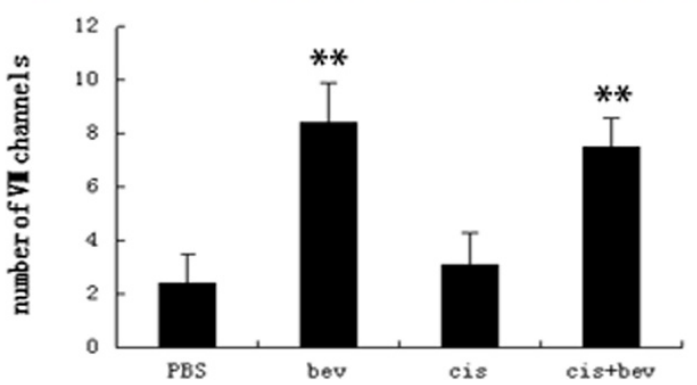

Figure 3 Anti-VEGF treatment induces increased VM. Comparison of VM channels in mice with various treatments. VM channels were positive for PAS staining and negative for CD34 staining in sections (arrow, $\times 400$ ). (A) PBS (B) bevacizumab (C) cisplatinp and(D) bevacizumab + cisplatin groups. (E) Comparison of VM channels in A, B, C and D. Tumors in the bevacizumab group formed more VM channels than that of PBS and cisplatin, and bevacizumab + cisplatin groups. ${ }^{* *} \mathrm{P}<0.01$.

\section{Discussion}

Antiangiogenic therapy is one of the most significant advances in cancer treatment. Its clinical value has been investigated, but is still too limited. A number of recent clinical and preclinical observations have been reported.

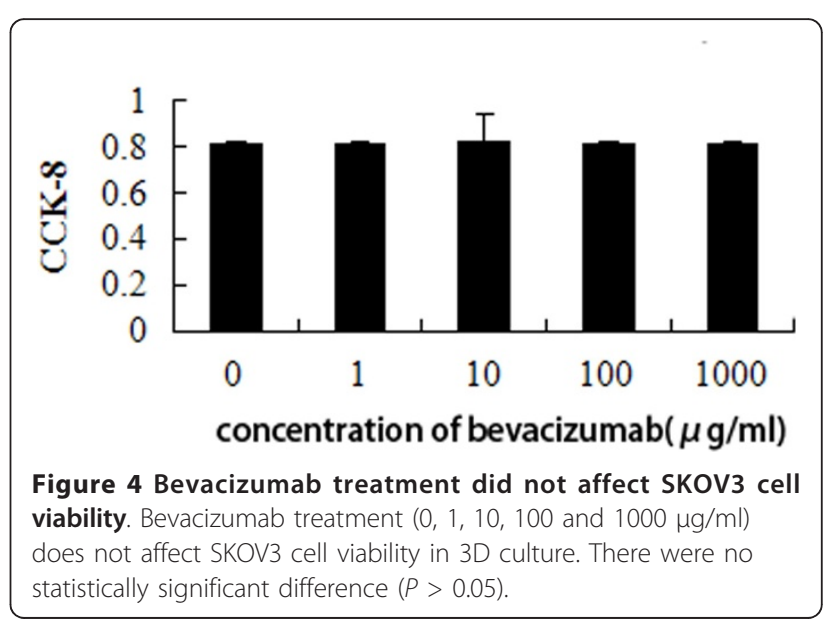




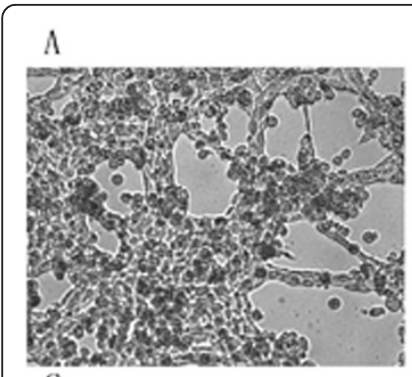

C
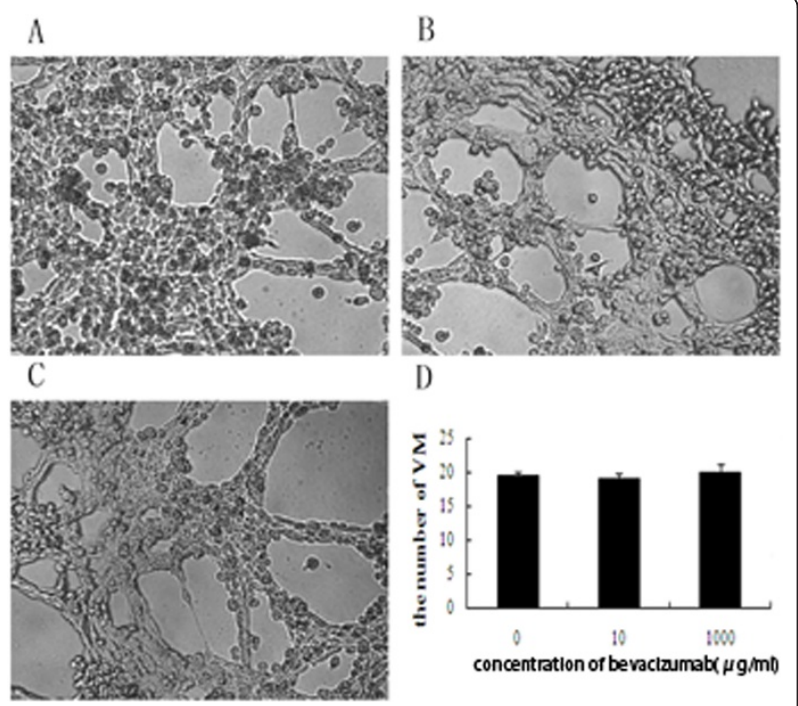

D

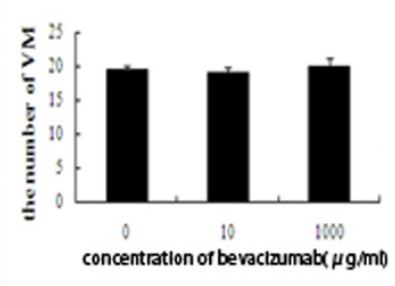

Figure 5 Bevacizumab treatment did not affect the number of tubules. The effect of bevacizumab $(0,10$ and $1000 \mu \mathrm{g} / \mathrm{ml})$ on the formation of VM channels (× 100). (A) Bevacizumab at O/(B) 10/(C) $1000 \mu \mathrm{g} / \mathrm{ml}$. (D) Bevacizumab treatment did not affect the number of tubules $(P>0.05)$.

In a neoadjuvant phase II trial of advanced epithelial ovarian cancer patients treated with the combinational therapy of carboplatin/paclitaxel with the angiogenesis inhibitor sorafenib, Pölcher $\mathrm{M}$ et al. reported that progressive disease was diagnosed in two patients out of four, and surgical exploration showed an increased number of peritoneal tumor implants [11]. Furthermore, after short-term treatment, varous forms of antiangiogenic therapy can lead to increased metastasis in mouse models of multiple tumor types $[12,13]$. Thus, there is a strong need to improve treatment strategies and to better understand the mechanisms of failure that hinder targeted antiangiogenic therapies. Here, we address the effect of short-term bevacizumab treatment using ovarian cancer xenografts. The data show that short-term bevacizumab treatment induces a reduction in tumor growth and an increase in distant tumor metastasis as measured by bioluminescence. Importantly, similar results were obtained when $\mathrm{nu} / \mathrm{nu}$ mice were treated with bevacizumab + cisplatin and cisplatin alone. It should be noted that in mouse models of ovarian cancer, antiangiogenic therapy can elicit an adaptive response involving increased dissemination and the emergence of distant metastasis.

To investigate this metastatic "conditioning" effect, a better understanding of the biological effects of antiVEGF treatment is required. Antiangiogenic therapy inhibits the development of new blood vessels, i.e. angiogenesis, resulting in reduced perfusion and an increase in intratumoral hypoxia, which may indirectly affect the tumor cells by inducing a more invasive phenotype in response to hypoxia, leading to increased invasion and metastatic dissemination $[14,15]$. HIF- $1 \alpha$ is a main regulator of the transcriptional response of cancer cells to hypoxia. By analyzing HIF- $1 \alpha$ expression using western blotting we showed that treatment with bevacizumab increases intratumoral hypoxia in metastasis models of ovarian cancer. While most tumors showed little or no expression of HIF- $1 \alpha$ protein in groups without bevacizumab treatment, HIF- $1 \alpha$ expression markedly increased both in bevacizumab and bevacizumab + cisplatin groups. In summary, short-term bevacizumab treatment results in increased of HIF- $1 \alpha$ expression. Interestingly, HIF- $1 \alpha$ regulates genes that are involved in angiogenesis, cell survival, invasion and metastasis [16]. Therefore, downstream pathways of HIF-1 $\alpha$ gene may contribute to metastatic phenotypes.

Current antiangiogenic strategies are mainly directed against tumor endothelial cells. However, tumours do not only rely on host blood vessels for nourishment, they can also form their own vasculature. The term "VM" has been used to describe the manner in which tumor cells mimic endothelial cells to form vasculogenic networks. VM has been described in ovarian cancer and some other highly aggressive tumors such as melanoma, prostatic carcinoma, breast cancer, soft tissue sarcomas and lung cancer [17-22]. The presence of VM correlates to an increased risk of metastasis and poor clinical outcome [23-26]. Several key molecules, including VE-cadherin, matrix metalloproteinases, laminin-5 $\gamma 2$ chain and EphA2, have been implicated in VM. Moreover, the tumor microenvironment, including hypoxia, ischemia and acidosis, plays a major role in trans-endothelial differentiation of aggressive tumor cells [27-30]. In the hypoxic microenvironment, melanoma cells increase HIF- $1 \alpha$ expression and induce the formation of VM channels to acquire an adequate blood supply [31]. In 3D culture, bevacizumab treatment for up to $48 \mathrm{~h}$ did not affect SKOV3 cell viability and the ability to form VM. Moreover, our data showed more VM channels in short-term bevacizumab treatment groups than those in control groups. This feature suggests that VM channels, which cannot be inhibited by bevacizumab, may satisfy the vascular requirements of ovarian cancer growth, invasion and metastasis during hypoxia. Thus, the increased of VM formation as a result of bevacizumabinduced hypoxia may increase dissemination and the emergence of distant metastasis. These findings offer a possible explanation for why antiangiogenesis only shows transitory clinical benefits.

\section{Conclusions}

VEGF inhibition causes hypoxia, induces HIF-1 $\alpha$ expression and the formation of $\mathrm{VM}$, which may be associated 
with tumor invasion and metastasis. Antiangiogenesis inhibits endothelium-dependent vessels, and then causes hypoxia in tumors. To compensate for tumor hypoxia, VM may increase to maintain the tumor blood supply and provide a convenient route for tumor metastasis. Another question raised by our results is whether other mechanisms linked to the hypoxic response could contribute to the metastatic phenotype, such as angiogenesis, growth factor signaling and apoptosis. The relationship between antiangiogenic therapy and metastasis remains to be determined and is an important topic for future research. Further study may provide additional drug targets, resulting in adjuvant therapies that can enhance the clinical benefits of antiangiogenic treatment.

\section{Acknowledgements}

We thank Jing Zhou for technical assistance.

\section{Author details}

'Department of Pharmacy, Shanghai First People's Hospital, School of medicine, Shanghai Jiao Tong University, No.100 Haining Road, Shanghai, 200080, China. 'Department of Orthopaedics, Yangzhou First People's Hospital, Jiangsu, China.

\section{Authors' contributions}

$X Y$ carried out the design of the experiments, performed most of experiments and drafted the manuscript. LQ participated in the design of the experiments, western blot and cell culture. LXY participated in statistical analysis and interpretation. YQY participated in animal experiments. XWW participated in the statistical analysis and helped drafting the manuscript. LGL participated in the design of the experiments and helped drafting the manuscript. All authors read and approved the final manuscript.

\section{Competing interests}

The authors declare that they have no competing interests.

Received: 29 December 2011 Accepted: 23 February 2012

Published: 23 February 2012

\section{References}

1. Folkman J: Tumor angiogenesis: therapeutic implications. N Engl J Med 1971, 285:1182-1186.

2. Samaranayake H, Määttä AM, Pikkarainen J, Ylä-Herttuala S: Future prospects and challenges of antiangiogenic cancer gene therapy. Hum Gene Ther 2010, 21(4):381-96.

3. Kerbel RS: Tumor angiogenesis. N Engl J Med 2008, 358:2039-2049.

4. Jain RK: Normalization of tumor vasculature: an emerging concept in antiangiogenic therapy. Science 2005, 307:58-62.

5. Qu B, Guo L, Ma J, LV Y: Antiangiogenesis therapy might have the unintended effect of promoting tumor metastasis by increasing an alternative circulatory system. Med Hypotheses 2010, 74(2):360-361.

6. Casanovas O, Hicklin DJ, Bergers G, Hanahan D: Drug resistance by evasion of antiangiogenic targeting of VEGF signaling in late-stage pancreatic islet tumors. Cancer Cell 2005, 8:299-309.

7. Rubenstein $J$, Kim J, Ozawa T, Zhang M, Westphal M, Deen DF, Shuman MA: Anti- VEGF antibody treatment of glioblastoma prolongs survival but results in increased vascular cooption. Neoplasia 2000, 2:306-314.

8. Kunkel P, Ulbricht U, Bohlen P, Brockmann MA, Fillbrandt R, Stavrou D, Westphal M, Lamszus K: Inhibition of glioma angiogenesis and growth in vivo by systemic treatment with a monoclonal antibody against vascular endothelial growth factor receptor-2. Cancer Res 2001, 61:6624-6628.
9. Cong R, Sun Q, Yang L, Gu H, Zeng Y, Wang B: Effect of Genistein on vasculogenic mimicry formation by human uveal melanoma cells. J Exp Clin Cancer Res 2009, 28:124.

10. Miyamoto T, Min W, Lillehoj HS: Lymphocyte proliferation response during Eimeria tenella infection assessed by a new, reliable, nonradioactive colorimetric assay. Avian Dis 2002, 46:10-16.

11. Pölcher M, Eckhardt M, Coch C, Wolfgarten M, Kübler K, Hartmann G, Kuhn W, Rudlowski C: Sorafenib in combination with carboplatin and paclitaxel as neoadjuvant chemotherapy in patients with advanced ovarian cancer. Cancer Chemother Pharmacol 2010, DOI 10. 1007/s00280010-1276-2.

12. Ebos JM, Lee CR, Cruz-Munoz W, Bjarnason GA, Christensen JG, Kerbel RS: Accelerated metastasis after short-term treatment with a potent inhibitor of tumor angiogenesis. Cancer Cell 2009, 15:232-239.

13. Pàez-Ribes $M$, Allen E, Hudock J, Takeda T, Okuyama H, Viñals F, Inoue M, Bergers $\mathrm{G}$, Hanahan D, Casanovas $\mathrm{O}$ : Antiangiogenic therapy elicits malignant progression of tumors to increased local invasion and distant metastasis. Cancer Cell 2009, 15:220-231.

14. Du R, Lu KV, Petritsch C, Liu P, Ganss R, Passegué E, Song H, Vandenberg S, Johnson RS, Werb Z, Bergers G: HIF1alpha induces the recruitment of bone marrow-derived vascular modulatory cells to regulate tumor angiogenesis and invasion. Cancer Cell 2008, 13:206-220.

15. Pennacchietti S, Michieli P, Galluzzo M, Mazzone M, Giordano S, Comoglio PM: Hypoxia promotes invasive growth by transcriptional activation of the met protooncogene. Cancer Cell 2003, 3:347-361.

16. Semenza GL: Development of novel therapeutic strategies that target HIF-1. Expert Opin Ther Targets 2006, 10:267-280.

17. Sood AK, Fletcher MS, Coffin JE, Yang M, Seftor EA, Gruman LM, Gershenson DM, Hendrix MJ: Functional role of matrix metalloproteinases in ovarian tumor cell plasticity. Am J Obstet Gynecol 2004, 190:899-909.

18. Sharma N, Seftor RE, Seftor EA, Gruman LM, Heidger PM Jr, Cohen MB, Lubaroff DM, Hendrix MJ: Prostatic tumor cell plasticity involves cooperative interaction of distinct phenotypic subpopulations: role in vasculogenic mimicry. The Prostate 2002, 50:189-201.

19. Shirakawa K, Wakasugi H, Heike Y, Watanabe I, Yamada S, Saito K, Konishi F: Vasculogenic mimicry and pseudo-comedo formation in breast cancer. Int J Cancer 2002, 99:821-828.

20. van der Schaft DW, Hillen F, Pauwels P, Kirschmann DA, Castermans K Egbrink MG, Tran MG, Sciot R, Hauben E, Hogendoorn PC, Delattre O, Maxwell PH, Hendrix MJ, Griffioen AW: Tumor cell plasticity in Ewing sarcoma, an alternative circulatory system stimulated by hypoxia. Cancer Res 2005, 65:11520-11528.

21. Van Rompaey L, Holland E, Grosveld G: TEL induces aggregation in transformed cells and induces tube formation in NIH3T3-UCLA cells. Biochem Biophys Res Commun 2002, 291:820-828.

22. Passalidou E, Trivella M, Singh N, Ferguson M, Hu J, Cesario A, Granone P, Nicholson AG, Goldstraw P, Ratcliffe C, Tetlow M, Leigh I, Harris AL, Gatter KC, Pezzella F: Vascular phenotype in angiogenic and nonangiogenic lung non-small cell carcinomas. Br J Cancer 2002, 86:244-249.

23. Maniotis AJ, Folberg R, Hess A, Seftor EA, Gardner LM, Pe'er J, Trent JM, Meltzer PS, Hendrix MJ: Vascular channel formation by human melanoma cells in vivo and in vitro: vasculogenic mimicry. Am J Pathol 1999, 155:739-752.

24. Folberg R, Rummelt V, Parys-Van Ginderdeuren R, Hwang T, Woolson RF, Pe'er J, Gruman LM: The prognostic value of tumor blood vessel morphology in primary uveal melanoma. Ophthalmology 1993, 100:1389-1398

25. Sun B, Zhang S, Zhao X, Zhang W, Hao X: Vasculogenic mimicry is associated with poor survival in patients with mesothelial sarcomas and alveolar rhabdomyosarcomas. Int J Oncol 2004, 25:1609-1614.

26. Yao LQ, Feng YJ, Ding JX, Xu CJ, Jin HY, Yin LH: Primary study of vasculogenic mimicry induced by hypoxia in epithelial ovarian carcinoma. Zhoughua Fu Chan Ke Za Zhi (Chinese) 2005, 40:662-665.

27. Hendrix MJ, Seftor EA, Hess AR, Seftor RE: Molecular plasticity of human melanoma cells. Oncogene 2003, 22:3070-3075.

28. Zhang S, Zhang D, Sun B: Vasculogenic mimicry: current status and future prospects. Cancer Lett 2007, 254:157-164.

29. Yao LQ, Feng YJ, Ding JX, Jing HM, Xu CJ, Chen SF, Su M, Yin LH: Characteristics and differentiated mechanism of vascular endothelial 
cells-like derived from epithelial ovarian cancer cells induced by hypoxia. Int J Oncol 2007, 30:1069-1075.

30. Hendrix MJ, Seftor RE, Seftor EA, Gruman LM, Lee LM, Nickoloff BJ, Miele L,

Sheriff DD, Schatteman GC: Transendothelial function of human

metastatic melanoma cells: role of the microenvironment in cell-fate determination. Cancer Res 2002, 62:665-668.

31. Sun B, Zhang D, Zhang S, Zhang W, Guo H, Zhao X: Hypoxia influences vasculogenic mimicry channel formation and tumor invasion-related protein expression in melanoma. Cancer Lett 2007, 249:188-197.

doi:10.1186/1756-9966-31-16

Cite this article as: Xu et al.: Short-term anti-vascular endothelial growth factor treatment elicits vasculogenic mimicry formation of tumors to accelerate metastasis. Journal of Experimental \& Clinical Cancer Research 2012 31:16

Submit your next manuscript to BioMed Central and take full advantage of:

- Convenient online submission

- Thorough peer review

- No space constraints or color figure charges

- Immediate publication on acceptance

- Inclusion in PubMed, CAS, Scopus and Google Scholar

- Research which is freely available for redistribution

Submit your manuscript at www.biomedcentral.com/submit 